\title{
Delayed Menarche and Amenorrhea in Ballet Dancers
}

\section{Citation}

Frisch, Rose E., Grace Wyshak, and Larry Vincent. 1980. “Delayed Menarche and Amenorrhea in Ballet Dancers." N Engl J Med 303 (1) (July 3): 17-19. doi:10.1056/nejm198007033030105.

\section{Published Version}

doi:10.1056/NEJM198007033030105

\section{Permanent link}

http://nrs.harvard.edu/urn-3:HUL.InstRepos:16953387

\section{Terms of Use}

This article was downloaded from Harvard University's DASH repository, and is made available under the terms and conditions applicable to Other Posted Material, as set forth at http:// nrs.harvard.edu/urn-3:HUL.InstRepos:dash.current.terms-of-use\#LAA

\section{Share Your Story}

The Harvard community has made this article openly available.

Please share how this access benefits you. Submit a story.

Accessibility 
In our patient, after the initiation of antineoplastic chemotherapy, a precipitous fall in the serum lactate concentration occurred, accompanied by the restoration of a normal $\mathrm{L} / \mathrm{P}$ ratio and correction of metabolic acidosis (Fig. 1). Rapid involution of Hodgkin's disease occurred simultaneously, evidenced by complete disappearance of the parotid swellings and submandibular lymphadenopathy and a marked diminution in the liver size. This therapeutic response suggests that the lactic acidosis could be attributed directly to the Hodgkin's disease.

Although administration of massive amounts of intravenous bicarbonate may be imperative in the initial treatment of patients with severe lactic acidosis, this therapy is not without hazards since lethal hyperosmolality has been observed. ${ }^{13,14}$ In addition, recent studies in animals have also provided evidence suggesting detrimental effects of bicarbonate in the treatment of experimentally induced lactic acidosis. ${ }^{15}$

The evidence reported here suggests that when lactic acidosis is associated with Hodgkin's disease, the successful reversal of this potentially lethal metabolic derangement may depend on the prudent institution of effective antineoplastic chemotherapy rather than on bicarbonate administration alone. Chemotherapy may have importance in the treatment of patients with lactic acidosis in other neoplasms that are susceptible to specific therapy. ${ }^{2,4,5}$

\section{REFERENCES}

1. Scheerer PP, Pierre RV, Schwartz DL, Linman JW. Reed-Sternbergcell leukemia and lactic acidosis: unusual manifestations of Hodgkin's disease. N Engl J Med. 1964; 270:274-81.

2. Field M, Block JB, Levin R, Rall DP. Significance of blood lactate elevations among patients with acute leukemia and other neoplastic proliferative disorders. Am J Med. 1966; 40:528-47.

3. Roth GJ, Porte D Jr. Chronic lactic acidosis and acute leukemia. Arch Intern Med. 1970; 125:317-21.

4. Block JB. Lactic acidosis in malignancy and observations on its possible pathogenesis. Ann NY Acad Sci. 1974; 230:94-102.

5. Wainer RA, Wiernik PH, Thompson WL. Metabolic and therapeutic studies of a patient with acute leukemia and severe lactic acidosis of prolonged duration. Am J Med. 1973; 55:255-60.

6. Kachel RG. Metastatic reticulum cell sarcoma and lactic acidosis Cancer. 1975; 36:2056-9.

7. Spechler SJ, Esposito AL, Koff RS, Hong WK. Lactic acidosis in oa cell carcinoma with extensive hepatic metastases. Arch Intern Med. 1978; 138:1663-4.

8. Oliva PB. Lactic acidosis. Am J Med. 1970; 48:209-25.

9. Waters WC III, Hall JD, Schwartz WB. Spontaneous lactic acidosis: the nature of the acid-base disturbance and considerations in diagnosis and management. Am J Med. 1963; 35:781-93.

10. Relman AS. Lactic acidosis. In: Brenner BM, Stein JH, eds. Acid-base and potassium homeostasis. New York: Churchill Livingstone, 1978: 65-100.

11. Block JB, Bronson WR, Bell WR. Metabolic abnormalities of lactic acid in Burkitt-type lymphoma with malignant effusions. Ann Intern Med. 1966; 65:101-8.

12. Huckabee WE. Abnormal resting blood lactate. II. Lactic acidosis. Am J Med. 1961; 30:840-8.

13. Máttar JA, Weil MH, Shubin H, Stein L. Cardiac arrest in the critically ill. II. Hyperosmolal states following cardiac arrest. Am J Med. 1974; 56:162-8.

14. Simmons MA, Adcock EW III, Bard H, Battaglia FC. Hypernatremia and intracranial hemorrhage in neonates. N Engl J Med. 1974; 291:610.

15. A rieff AI, Leach WJ, Lazarowitz VC. Effects of $\mathrm{NaHCO}_{3}$ in therapy of experimental lactic acidosis. Proc Ann Meeting Am Soc Nephrol. 1978; 11:11A. abstract.

\section{DELAYED MENARCHE AND AMENORRHEA IN BALLET DANCERS}

\author{
Rose E. Frisch, Ph.D., Grace Wyshak, Ph.D., \\ AND LARry Vincent, M.D.
}

$\mathrm{Y}^{\circ}$ OUNG female ballet dancers attending professional schools or dancing in companies in which thinness is much admired restrict their food intake and are highly active. ${ }^{1}$ The unusual eating habits and levels of activity of some of these dancers have been related to lack of menstrual cycles. ${ }^{1}$ Amenorrhea and late menarche among girls and women with average activity levels are associated with undernutrition ${ }^{2}$ and weight loss in the range of 10 to 15 per cent of the normal weight for height ${ }^{3-5}$; such weight loss apparently reduces the fat/lean ratio to less than a critical level. ${ }^{3}$

We report here on 89 young ballet dancers among whom there was a high incidence of primary amenorrhea, secondary amenorrhea, irregular cycles, and delayed menarche - an incidence correlated with excessive thinness.

\section{Subjects AND Methods}

A questionnaire on age, height, weight, duration of training, age of menarche, and menstrual periodicity was distributed to 89 dancers. The respondents were studying at three professional ballet schools in highly competitive programs: 58 were scholarship students, and 10 were members of a professional apprentice company.

Two dancers did not know at what age menarche had begun Dancers of age 16 years and older who reported "no menarche yet" were classified as having primary amenorrhea; lack of cycles for longer than three consecutive months was classified as secondary amenorrhea. Intervals between menstruations of more than 38 days but less than three months were classified as irregular cycles.

Total body water, expressed as the per cent of body weight - a measure of relative fatness - was estimated for each girl from her height and weight. ${ }^{3}$ Body leanness may have been underestimated, since it is likely that in dancers, as compared with untrained women or girls, more of the weight is muscle.

\section{RESULTS}

The data are summarized in Table 1. Ten per cent (nine) of the group reported primary amenorrhea occurring at $18.5 \pm 0.5$ years (mean \pm S.E.M.); six were older than 18.0 years (one was 19.9 and another 20.6). Twelve per cent (11) of the dancers reported that they had not undergone menarche at $14.3 \pm 0.4$ years; five were in their 15 th year. Fifteen per cent (13) of the group reported secondary amenorrhea, and 30 per cent (27) reported irregular cycles. Thirty-three per cent (29) of the dancers reported regular cycles.

The mean age at menarche reported by 67 of the 69 postmenarcheal dancers was $13.7 \pm 0.1$ (1.2 S.D.) years, which is significantly later $(\mathrm{P}<0.001)$ than the mean ages of $12.8 \pm 0.05^{6}$ and $12.9 \pm 0.1$ years ${ }^{7}$ report-

From the Center for Population Studies, Harvard School of Public Health, Cambridge; the Department of Preventive and Social Medicine, Harvard Medical School, Boston; and the Department of Radiology, St. Vincent's Hospital, New York (address reprint requests to Dr. Frisch at the Center for Population Studies, 9 Bow St., Cambridge, MA 02138) 
ed for American girls. Probit analysis could not be used to estimate the mean age of the whole group because of the high percentage of older dancers reporting "no menarche yet"; the data therefore did not conform to a sigmoid curve.

Dancers with amenorrhea and with irregular cycles were significantly leaner than dancers reporting regular cycles (Table 1). The 20 dancers of all ages reporting "no menarche yet" were significantly leaner than the dancers of the three other groups $(F=7.69$, $\mathbf{P}<0.01$ ). As is indicated by their average total body water as per cent of body weight, the weight for height of each of these dancers was below the critical weight for height necessary for menarche or the maintenance of regular cycles in well-nourished women ${ }^{3}$ with average activity. Their weights for height are also below the standard termed "underweight" for young women. ${ }^{8}$ Even the dancers in the group with regular cycles also were in the very low range of weight for height $^{8}$ and relative fatness for their age ${ }^{3}$; however, all but one of them were above the threshold, minimum weights for menarche or maintenance of cycles. ${ }^{3}$ Two dancers reporting irregular cycles were in the range of normal fatness for maintaining cycles, demonstrating that the weight is necessary but not sufficient for cycles to occur ${ }^{3}$; emotional or physical stress may override the effect of weight.

The mean height $(158.7 \pm 1.2 \mathrm{~cm})$ of the 11 dancers reporting "no menarche yet" at a mean age of $14.3 \pm 0.4$ years (Table 1 ) was similar to the height $(158.5 \pm 0.5 \mathrm{~cm})$ of well-nourished non-dancers at menarche at $12.9 \pm 0.1$ years, but the mean weight of the dancers $(42.0 \pm 0.9 \mathrm{~kg})$ was significantly less than that of the well-fed girls $(47.8 \pm 0.5 \mathrm{~kg})(\mathrm{P}<0.001){ }^{7}$

\section{Discussion}

The relatively late mean age at menarche and the delayed menarche of the dancers may show that late maturers choose to be ballet dancers or that the hard training and low food intake typical of ballet dancers cause excessive thinness that delays puberty. ${ }^{3}$ The fact that most of the dancers began their training at young ages (Table 1), and the high incidence of secondary amenorrhea and irregular cycles suggest that the latter factors - hard training and low intake contribute strongly to this phenomenon.

Warren has reported a late mean age of menarche, 15.4 years, for 13 selected young ballet dancers, in association with thinness and the energy drain of hard training. ${ }^{9}$ A sample group of women runners also had a relatively late age at menarche and a high incidence of amenorrhea, the latter positively correlated with the number of miles run per week. ${ }^{10}$ Finally, highschool and college athletes have a statistically significant later age at menarche than do nonathletes. ${ }^{11}$

The occurrence of menarche after an injury preventing dancing ${ }^{1,9}$ supports the hypothesis that a change in fat/lean ratio $^{3}$ and the accompanying changes in metabolic ${ }^{12}$ and hormonal levels ${ }^{13}$ characteristic of hard physical exercise may be involved in the delay of menarche and menstrual disturbances in these ballet dancers. A change in the ratio may also result from an increase in leanness, in addition to a decrease in fatness, without weight loss or even with weight gain, as found in many athletes (Frisch RE, Welbergen A, McArthur JW, Albright T, Bullen B, Witschi J, Reed RB: unpublished data). ${ }^{14}$

We are indebted to E. L. Lowenkopf, M.D., for his assistance in collecting the data.

\section{REFERENCES}

1. Vincent LM. Competing with the sylph: dancers and the pursuit of the ideal body form. Kansas City, Kansas: Andrews and McMeel, 1979.

2. Frisch RE. Weight at menarche: similarity for well-nourished and undernourished girls at differing ages, and evidence for historical constancy. Pediatrics. 1972; 50:445-50.

3. Frisch RE, McArthur JW. Menstrual cycles: fatness as a determinant of

Table 1. Characteristics of 89 Ballet Dancers Reporting Lack of Menstrual Cycles, Irregular Cycles, and Regular Cycles.*

\begin{tabular}{|c|c|c|c|c|c|c|}
\hline $\begin{array}{c}\text { Group } \\
\text { Classification } \\
\text { (No. IN Group) }\end{array}$ & $\begin{array}{l}\text { AGE AT } \\
\text { TIME OF } \\
\text { STUdY }\end{array}$ & $\begin{array}{c}\text { AGE AT } \\
\text { MENARCHE }\end{array}$ & $\begin{array}{l}\text { AgE AT } \\
\text { Start Of } \\
\text { Training }\end{array}$ & HEIGHT & WeIGHT & $\begin{array}{l}\text { Estimated } \\
\text { TW/BWt }+\end{array}$ \\
\hline & $y r$ & $y r$ & $y r$ & $\mathrm{~cm}(\mathrm{in})$ & $k g(b)$ & $\%$ \\
\hline $\begin{array}{l}\text { Primary amenorrhea - } \\
\text { age }>16(9)\end{array}$ & $18.4 \pm 0.5$ & Not yet & $8.4 \pm 0.9$ & $\begin{array}{l}163.7 \pm 1.3 \\
(64.4 \pm 0.5)\end{array}$ & $\begin{array}{l}43.5 \pm 0.5 \ddagger \\
(95.7 \pm 1.1)\end{array}$ & $59.5 \pm 0.6 \S$ \\
\hline $\begin{array}{l}\text { No menarche yet - } \\
\text { age }<16(11)\end{array}$ & $14.3 \pm 0.4$ & Not yet & $6.7 \pm 0.5$ & $\begin{array}{l}158.7 \pm 1.2 \\
(62.5 \pm 0.5)\end{array}$ & $\begin{array}{l}42.0 \pm 0.9 \text { §ा } \\
(92.4 \pm 2.0)\end{array}$ & $58.9 \pm 0.4 \S$ \\
\hline Secondary amenorrhea (13) & $17.9 \pm 0.4$ & $14.3 \pm 0.4 \ddagger$ & $7.8 \pm 0.4$ & $\begin{array}{l}162.7 \pm 1.4 \\
(64.1 \pm 0.6)\end{array}$ & $\begin{array}{c}44.9 \pm 1.6 \\
(98.8 \pm 3.5)\end{array}$ & $58.3 \pm 0.7 \ddagger$ \\
\hline Irregular cycles (27) & $16.7 \pm 0.3$ & $13.9 \pm 0.3 \ddagger \|$ & $7.2 \pm 0.7$ & $\begin{array}{l}163.5 \pm 0.9 \\
(64.4 \pm 0.4)\end{array}$ & $\begin{array}{c}45.9 \pm 0.7 \\
(101.0 \pm 1.5)\end{array}$ & $57.7 \pm 0.4 \ddagger$ \\
\hline Regular cycles (29) & $17.0 \pm 0.4$ & $13.3 \pm 0.2 \|$ & $7.4 \pm 0.4$ & $\begin{array}{l}162.0 \pm 1.0 \\
(63.8 \pm 0.4)\end{array}$ & $\begin{array}{c}47.0 \pm 0.8 \\
(103.4 \pm 1.8)\end{array}$ & $56.3 \pm 0.5$ \\
\hline All subjects (89) & $16.8 \pm 0.2$ & & $7.4 \pm 0.3$ & $\begin{array}{l}162.3 \pm 0.5 \\
(63.9 \pm 0.2)\end{array}$ & $\begin{array}{c}45.5 \pm 0.5 \\
(100.1 \pm 1.1)\end{array}$ & $57.6 \pm 0.3$ \\
\hline
\end{tabular}


minimum weight for height necessary for their maintenance or onset. Science. 1974; 185:949-51.

4. Vigersky RA, Anderson AE, Thompson RH, Loriaux DL. Hypothalamic dysfunction in secondary amenorrhea associated with simple weight loss. N Engl J Med. 1977; 297:1141-5.

5. Schindler AE, Frick V, Mikschi M, et al. Evaluation and long-term Pancheri P, eds. Psychoneuroendocrinology in reproduction. Amsterdam: Elsevier/North-Holland, 1979:263-74.

6. Zacharias L, Rand WM, Wurtman RJ. A prospective study of sexual development and growth in American girls: the statistics of menarche. Obstet Gynecol Surv. 1976; 31:325-37. of menarche. Arch Dis Child. 1971; 46:695-701.

8. Sargent DW. Weight-height relationship of young men and women. Am J Clin Nutr. 1963; 13:318-25.

9. Warren MP. The effects of exercise on pubertal progression and reproductive function in girls. Endocrinology. 1979; 104:239. abstract.

10. Feicht CB, Johnson TS. Martin BJ, et al. Secondary amenorrhoea in athletes. Lancet. 1978; 1:1145-6.

11. Malina RM, Spirduso WW, Tate C, Baylor AM. Age at menarche and selected menstrual characteristics in athletes at different competitive levels and in different sports. Med Sci Sports. 1978; 10:218-22.

12. Soman VR, Koivisto VA, Deibert D, et al. Increased insulin sensitivity and insulin binding to monocytes after physical training. N Engl J Med.

13. Sutton JR, Coleman MJ, Casey J, Lazarus L. Androgen responses during physical exercise. Br Med J. 1973; 2:520-2.

14. Pařizková J. Physical activity and body composition. In: Brožek J, ed. Human body composition: approaches and applications. Vol. VII. Oxford: Pergamon Press, 1965:161-76. follow-up of patients with psychogenic amenorrhea. In: Zichella L,

7. Frisch RE, Revelle R. Height and weight at menarche and a hypothesis 1973; 301:1200-4.

Frequently, however, they progress to a more serious clinical stage characterized by dysarthria, ataxia, seizures, dementia, or coma. The definitive diagnosis of this syndrome is usually established at autopsy by the histopathological finding in the brain tissue of demyelination accompanied by multifocal necrosis, astrocytosis, and occasionally dystrophic calcifications. ${ }^{6-9}$

The cerebrospinal fluid of 39 patients who had acute lymphoblastic leukemia and had been treated with cranial irradiation and intrathecal methotrexate was examined for the presence of myelin basic protein, a specific component of the myelin sheath and an indicator of demyelination. ${ }^{10,11}$ Increased levels of this protein (>4 ng per milliliter) were detected in all seven patients with clinically overt necrotizing leukoencephalopathy. Furthermore, serial determinations in two patients demonstrated that increasing levels of myelin basic protein in the cerebrospinal fluid correlated with disease progression and likewise returned to normal with resolution of clinical symptomatology.

\section{Methods}

\section{Patients}

\section{LEUKOENCEPHALOPATHY AND ELEVATED LEVELS OF MYELIN BASIC PROTEIN IN THE CEREBROSPINAL FLUID OF PATIENTS WITH ACUTE LYMPHOBLASTIC LEUKEMIA}

\author{
Diamon Gangji, M.D., Gregory H. Reaman, M.D., \\ Stephen R. Cohen, Ph.D., \\ W. Archie Bleyer, M.D., \\ and David G. Poplack, M.D.
}

$\mathrm{A}^{\mathrm{s}}$ the survival of patients with acute lymphoblastic leukemia has improved, increased attention has focused on the potential toxicity and adverse long-term sequelae of antileukemic therapy. In particular, there is considerable interest in the toxic effects on the central nervous system that may result from therapy to treat or prevent meningeal leukemia. A wide range of neurotoxicities have been described, the most serious of which is the syndrome of necrotizing leukoencephalopathy associated with cranial irradiation and the administration of methotrexate. ${ }^{1-5}$ Clinically, patients with this delayed form of neurotoxicity present with symptoms such as poor performance in school, forgetfulness, and confusion.

From the Pediatric Oncology Branch, National Cancer Institute; the Department of Neurochemistry, Johns Hopkins University, Baltimore; and the departments of Pediatrics and Radiation Oncology, University of Washington, Seattle (address reprint requests to Dr. Gangi at Bldg. 10, Room 3B-03, National Cancer Institute, Bethesda, MD 20205).

Dr. Gangji is a Fellow of the Rose et Jean Hoguet Cancer Research Foundation; Dr. Bleyer is a Scholar of the Leukemia Society of America; Dr. Cohen is a recipient of a grant (14167) from the National Institutes of Health.
Cerebrospinal fluid was obtained from 39 patients who had acute lymphoblastic leukemia and were three to 20 years of age. The patients were categorized into four groups.

Group I consisted of seven patients with clinically overt signs and symptoms of necrotizing leukoencephalopathy. All had received cranial irradiation (2400 rads) and multiple doses of intrathecal methotrexate for central-nervous-system prophylaxis. Two patients had received additional therapy for meningeal leukemia before the onset of leukoencephalopathy. The diagnosis of leukoencephalopathy was made on the basis of characteristic clinical findings ${ }^{9-18}$ and the exclusion of other possible causes of encephalopathy or demyelination.

Group II consisted of 21 patients who had previously completed central-nervous-system prophylaxis consisting of cranial irradiation (2400 rads) and multiple doses of intrathecal methotrexate. Cerebrospinal-fluid samples were obtained from one month to $6 \frac{1}{2}$ years after completion of central-nervous-system prophylaxis. Sixteen of the 21 patients were still receiving systemic maintenance chemotherapy without any intrathecal or intravenous methotrexate.

Group III consisted of seven patients undergoing centralnervous-system prophylaxis. Cerebrospinal fluid was obtained from these patients during the time of prophylactic treatment, which consisted of cranial irradiation and intrathecal methotrexate. All these patients were being treated with cranial irradiation and had received at least two doses of intrathecal methotrexate when samples of cerebrospinal fluid were obtained.

Group IV consisted of four patients with meningeal leukemia. These patients were receiving therapy for active meningeal leukemia when cerebrospinal-fluid samples were obtained. All four had received cranial irradiation and intrathecal methotrexate as prophylaxis and were being treated for meningeal leukemia with intralumbar or intraventricular methotrexate (two patients). All had a leukemic pleocytosis in the cerebrospinal fluid at the time of study.

\section{Collection of Cerebrospinal Fluid}

Cerebrospinal fluid $(1 \mathrm{ml})$ was obtained from patients by lumbar puncture or Ommaya reservoir sampling either at the time of 